\author{
Divis Flats: \\ The Social and Political Implications of a Modern Housing Project \\ in Belfast, Northern Ireland, 1968-1998 \\ Megan Deirdre Roy
}

Contemporary architecture and, still more, urban planning are closely connected with social problems. We should keep abreast of these developments through our own investigations, but I strongly urge that we steer clear of political and social problems in our meetings. They are extremely complex and, moreover, raise further economic problems. We are not qualified to discuss these difficult subjects. ${ }^{1}$

- Le Corbusier

To build city districts that are custom made for easy crime is idiotic, yet that is what we do. ${ }^{2}$

- Jane Jacobs

The Divis Flats, located at the bottom of the Falls Road in West Belfast, was a complex of 12 interconnected eight story deck access blocks and one 20 story tower, the top of which doubled as a base for the British Army. The complex was built between 1968 and 1972 by the John Laing Construction Company, right in the midst of a time defined by high modernist architecture and the Utopian visions of Le Corbusier's modern machines-for-living. It housed roughly 2,400 residents amongst the 850 flats, of which 98 percent were self-identified Catholics. ${ }^{3}$ The structure was a steel frame with concrete in situ slabs for the floors and walls, internally insulated with asbestos boards and plaster.

Modernist structures like Divis Flats were perceived as the rational answer to post-World War II housing shortages. However, in the context of brewing political conflict in Northern Ireland, the failures of such Modernism became quickly amplified. This same period of time saw the construction of mass housing throughout Europe and the U.S., and included such complexes as the notoriously crime-ridden Pruitt-Igoe in St. Louis (whose 1972 demolition symbolized the "death of Modernism"4) and the Unité d'Habitation in Marseilles, France. In terms of architectural design, the Divis Flats in Belfast differed from its contemporaries in extremely striking ways, including the irregular arrangement of buildings, the presence of continuous terraces, and a lack of social amenities and landscaping. Such irregularities in design, which contributed to feelings of insecurity, can be 
better understood in the context of more than 30 years of conflict in Northern Ireland, as a minority Catholic population came under the watchful eye of the British state.

The 12 buildings of the Divis complex were accessible from three different levels of linked terraces: "walks," "paths" and "rows." Because the terraces were connected throughout the complex, an individual could potentially walk along the top row from St. Jude's block all the way to St. Comgall's block without having to go up or down stairs. While such design eliminated any sense of privacy or ownership for residents, it did make it easy for British troops to go on daily patrols throughout the complex. Additionally, a close analysis of the buildings reveals that nearly every front door was oriented toward the Army's post on the top of Divis Tower. Because the British Army became viewed as the enemy to most Catholics after the rioting and violence of 1971, this design was perceived as a threat to, not insurer of, community security.

The residents of the flats came from mostly impoverished working class backgrounds. Unemployment rates consistently hovered around 68 percent in the Falls area (similar levels of unemployment were seen at Chicago's South Side Taylor Homes in the $1980 \mathrm{~s}^{5}$ ), and a shocking 51 percent of Divis residents depended entirely on welfare assistance to provide for their families. ${ }^{6}$ Because Belfast's shipping and textiles industries were on the periphery of the European market, the economy was quickly and disproportionately affected by the recessions of 1973 and 1979. By 1982, Northern Ireland had the highest unemployment rates in the United Kingdom with roughly 113,000 people in the province out of work, a staggering 19.7 percent of the population. ${ }^{7}$

The 12 deck-access blocks of Divis Flats were completely demolished in 1993, following outcry from various residents groups, politicians and the media. However, the 20-floor tower remains standing to this day and was finally in the process of "demilitarization" in the summer of 2005. The tower has been an ominous presence on the lower Falls, maintaining a watchful eye over Belfast's republican community for the last 35 years. Kevin "Count" McCormack, an employee at the Divis Community Center commented that "they're probably listening in on our conversation right now, you know, with all their high-tech equipment. I'm sure that they saw you walk in here." 8 Whether or not the military still monitors the community to such an extent is certainly debatable, but the Panopticon-like paranoia that has become engrained in the minds of Falls residents is undeniable.

In examining the relationship between the Divis Flats and the violent "Troubles" of this area of Belfast, one must ask: is it mere coincidence that conflict first erupted the year after construction began? Or that a successful IRA cease-fire was declared and the Downing Street Agreement signed the very same year the blocks were demolished?

Many scholars dismiss architecture's inherent role in shaping society, just as they dismiss the role that socio-economics play in causing conflict. Perhaps this denial is rooted in fears of moral obligation. However, in examining a case like the 


\section{Divis Flats}

Divis Flats, which rapidly deteriorated into a trash-ridden, mold and rat-infested cesspool of vandalism, drug abuse and crime, one can clearly see that architectural design, specifically a lack of security and amenities, not only encouraged social ills, but simultaneously contributed to social unrest. In her essay "The Architecture of Deceit", theorist Diane Ghirardo writes,

The position that only formal elements matter in architecture bespeaks a monumental refusal to confront serious problems; it avoids a critique of the existing power structure, of the ways power is used, and of the identity of those whose interests power serves. To do otherwise might entail opening a Pandora's box of far more complicated issues. ${ }^{9}$

This article attempts to examine both the physical and psychological effects of the design of Divis Flats, within the context of Northern Ireland's most violent era, in order to show that architecture was one of many contributors to civil unrest.

The Troubles of Northern Ireland have continuously been labeled a sectarian conflict; a native Catholic minority pitted against a Protestant majority. Conflict has also been examined extensively within the context of national and cultural identity. ${ }^{10}$ However, such reductionist explanations overlook inherent questions of socio-economic inequity that were established over 400 years ago, through the British plantation system. The reality is that even today, two and a half times as many Catholics as Protestants are unemployed in Northern Ireland. ${ }^{11}$ And while civil conflict has been predominantly concentrated in the poverty-stricken neighborhoods of West Belfast, middle-class suburbs have remained comparatively peaceful. There, educated Protestants and Catholics live and work amongst each other. It is interesting to note that the primary social concern for individuals who live in these suburbs is, in fact, "The Troubles." Meanwhile, for residents of the city's western working-class districts, where pockets of Catholics and Protestants have become increasingly segregated in an attempt to find safety in numbers, the primary concerns have been low wages, unemployment and the high cost of living. ${ }^{12}$ This phenomenon will be addressed further, as it supports the argument that physiological and psychological insecurity have fueled civil unrest to a greater degree than political or national allegiance.

An examination of 30 years of conflict in West Belfast, particularly on the Lower Falls Road and at the Divis complex, exposes the insecure social conditions that have motivated impoverished young Catholic men to fight in order to protect their communities. Ultimately, the battle for security at the Divis Flats complex exposes a side to republicanism that has been largely ignored by the popular media: the Irish Republican Army's fundamental role in community policing and defense, made necessary, in part, through poor architectural design. 


\section{The Evolution of Support for Irish Republicanism}

A thorough examination of the course of conflict in Northern Ireland since 1969 exposes two distinct sources of republican paramilitary support: first is general lack of faith in the political system; second is fundamental need for security. It is this second source of allegiance toward the IRA and its various branches - including the Officials, the Provisionals, the Irish National Liberation Army (INLA), and more recently the "Real" IRA and the "Continuity" IRA, which is directly related to the built environment - which I examine.

Leaving Belfast's city center and heading toward the western part of the city, one enters Divis Street and very quickly crosses over the M1 highway. This highway was completed in 1984 to accommodate residents of the ever-expanding suburbs who commute to work. But the M1 was initially planned in the early 1960s and went hand in hand with the massive "slum clearance" programs that saw the destruction of the tightly-knit Catholic Pound Loney neighborhood, and the subsequent building of the high-rise Divis Flats to house the masses at increased densities. ${ }^{13}$ Just past the highway, on the left side of Divis Street stands the imposing Divis Tower, with "Demilitarize Now" graffiti all over its walls. Across the street from the tower, a number of traditional terrace-style houses are being completed, and behind the tower are similar units. In fact, this area is now a series of intimatefeeling cul-de-sacs of row houses, with the Divis Community center remaining in the middle. Children ride their bikes in the back streets, dogs patrol the sidewalks, and gardens are planted in fenced-in front courtyards. But this neighborhood was not always so safe for its residents.

Today, the predominantly Catholic Falls Road lies just to the south of the predominantly Protestant Shankill Road, the two areas being physically divided by a "Peace Line" of corrugated steel and barbed wire. This barrier, which is actually one of 13 walls built in the late 1970s and early 1980s, can only be crossed along a number of thoroughfares, including Northumberland Street, only blocks from the Divis complex.

In the middle of the $19^{\text {th }}$ century Belfast's linen industry had rapidly developed in the Falls area, which had acquired its name from the streams that flowed from Table Mountain east toward the river Lagan, and which powered the mills. At this time, the Falls was home to a mix of Protestant and Catholic factory workers, all of whom lived in traditional two up-two down row houses. However, the city became progressively segregated as Belfast's economy declined and competition for jobs increased. "At any time before 1969, the level of segregation in Belfast was directly proportional to the level of conflict in the city," writes one urban planner. ${ }^{14}$ This conflict between the Catholic and Protestant working classes came about as the result of Catholic insistence on equality, at the perceived expense of Protestant economic advantage. 


\section{Divis Flats}

Beginning in the late 1960s, in the wake of marches and demonstrations by the Northern Ireland Civil Rights Association (NICRA), clashes between Protestants and Catholics in this interface area became increasingly violent. The leaders of NICRA had been directly inspired by the civil rights movement in the United States, and sought to bring attention to discrimination against Catholics in employment and housing. The organization utilized peaceful forms of protest, primarily marches, to convey their message of equality. However, the group was quickly viewed as a threat to working-class Protestants who perceived demonstrations as a front for republicanism. NICRA actually emerged in 1967 out of an organization called the Derry Housing Action Committee, led by a nationalist MP from County Tyrone, Austin Currie.

The first civil rights marches indirectly brought about the resurgence of the Irish Republican Army. The IRA had been largely inactive since the border campaigns of the 1950s, and its leaders in Dublin were thought to be out of touch with the problems Catholics faced up north. On October 5, 1968, rioting first broke out in Northern Ireland when a NICRA march in Derry was stopped by the RUC. A number of marchers were beaten back by the police, and Catholics became enraged when the violent footage was aired on television.

The burning of over 80 Catholic homes around Clonard Monastery and Bombay Street following NICRA marches in August of 1969 drove many in the nationalist community to seek safety at the new Divis Flats. Belfast geographer Frederick Boal explains that, "the narrow zone of residential mixing along Cupar Street disappeared - it might be said that the buffer zone within the frontier had collapsed to a line." 15 From 1969 to 1976, it's estimated that anywhere from 35,000 to 60,000 Catholics were displaced from their homes. ${ }^{16}$ The trend toward increased sectarian segregation continued throughout the 1970s and 1980s, with a patchwork of insular neighborhoods, including the Catholic New Lodge, Ardoyne and Short Strand, and the Protestant Sandy Row and Donegall Pass developing.

It could be said that the birth of the Provisional IRA took place on the very night of rioting, August 15, 1969. It was then that three masked men took guns to the roof of St. Comgall's school near Divis Flats and held off a loyalist mob. Unfortunately, that night also saw the first casualty of the modern Troubles, when nine-year-old Patrick Rooney was killed by RUC machine gun fire while laying in his bed at St. Brendan's Row in Divis Flats. The first known Protestant to be killed was a 26-year-old bystander named Herbert Roy, who was shot by an unknown source on the Crumlin Road.

The rioting and violence of 1969 galvanized support for the republican movement and the "Provisional" IRA, under the leadership of Sean MacStiofain, broke with the Marxist and more political "Official" IRA leadership in Dublin. In fact, this initial departure from political republicanism was the direct result of a perceived need for militant protection on the Falls road. While the Provisionals immediately perceived the British Army, brought in to replace the RUC as 
peacekeepers, as a legitimate target, the majority of Catholic residents did not feel similarly. It was not until a series of injuries in 1971 and 1972, at the hands of the Army, that public opinion began to change. So, while the Catholic community largely supported the IRA's defensive role in policing and protection, they did not always support their aggressive tactics.

Following a series of riots by frustrated Catholics in 1970, rubber bullets were introduced by the British Army in 1971. Their purpose was to break up the large crowds without potentially lethal force; however, it was quickly learned that a direct blow to the head at close range could easily kill an individual, especially a child. In August of 1971 the British government introduced a policy of internment for political prisoners, a vast majority of whom were Catholic nationalists. Under internment, a prisoner could be held for one week, with no access to a lawyer for the first 48 hours, and was subjected to 12 hours of interrogation a day. This treatment obviously caused a backlash in the Catholic community, who saw the measure as a sign of further repression and discrimination. Because an individual could be held on mere suspicion of or vague association with republicanism, it also meant feelings of greater alienation from British troops.

The events of 1972 caused an even greater rift between the Catholic community and the state when, on January 30, a NICRA march in Derry's Bogside resulted in the shooting deaths of 13 men. This event, commonly known as "Bloody Sunday," continues to be investigated; however, testimony that there was an armed IRA presence on that day is readily disputed. None of the men who were shot by the B-Specials, a specially trained paratroop unit, were found to have had weapons. In fact, many of them were shot in the back or with their hands on their heads in surrender. In the first government inquiry, Lord Widgery wrote that,

At one end of the scale some soldiers showed a high degree of responsibility; at the other, notably in Glenfada Park [where James Wray, Gerald Donaghy, William McKinney, and Gerald McKinney were shot] firing bordered on the reckless. These distinctions reflect differences in the character of the soldiers concerned. . .None of the deceased or wounded is proved to have been shot whilst handling a firearm or bomb. ${ }^{17}$

This event sparked a wave of rioting in Catholic districts all over Northern Ireland, and meant an increase in support for the IRA. In April of 1972, an eleven-year-old named Francis Rowntree was accidentally killed by a rubber bullet at the Divis Flats. As tragic as this event was it was, it was the number of premeditated murders that made 1972 the bloodiest year of in the entire conflict. There were 121 victims of sectarian assassination that year, and a shocking 80 of them came at the hands 


\section{Divis Flats}

of the recently formed Ulster Defense Association, led by ex-British soldier John White. One of his victims was local Irish folk singer Rose McCartney, who was abducted, tortured and machine-gunned with a friend on July 22. Journalist Jack Holland writes that:

White's theory about "terrorizing the terrorist" at least worked insofar as it terrified the population that supported the Provisional IRA. But since workingclass Catholics did not trust the security forces to protect them - between July 31 and December 31 only three Protestants were charged with murder - sectarian killings may have enhanced the position of the IRA. ${ }^{18}$

That same year, 20-year-old Divis schoolteacher Patrick McGee was mistakenly shot and killed by troops, while 80-year-old pensioner Paddy Donaghy was also killed in Divis Tower by Army gunfire. It's important to note that the elderly have always occupied Divis Tower, as they are naturally perceived as less of a threat to British forces. Although the particular acts of violence committed by Loyalist paramilitaries and the British Army were vastly different, support for the Provisionals was hardened by both threats. One resident of Divis flats explained, "when you've seen people shot or killed with plastic bullets, and when you've been harassed or arrested, you become a rebel - and there's plenty of Brit terror in Divis to make people rebels." 19

Ironically, the suspension of the Northern Irish government at Stormont in 1973 -a result of the mayhem of the previous year - was interpreted by the IRA as a political victory. They saw this as a sign that the British government was giving in to the pressures of the conflict; however, the Emergency Provisions Act, which was simultaneously implemented, was certainly not a good thing for republicans. It meant greater power to the RUC and Army in arresting and interrogating suspected IRA men. Loyalists also feared that the British government was giving in, and so the suspension of Stormont also resulted in the formation of a more radical unit of the UDA called the Ulster Freedom Fighters. The UFF's goal was to specifically target nationalist politicians. They intended to abduct SDLP leader Gerry Fitt in June of 1973, but ended up grabbing city councilor Paddy Wilson and his companion Irene Andrews instead. The two were eventually shot by members of the UFF, but not before they were each stabbed over 20 times, with Wilson's neck cut ear to ear. The IRA's way of answering attacks like this continued to be the targeting of the British state, and in July a booby trap killed three members of an Army patrol unit in Divis flats. However, attacks such as these did anything but protect the Catholic community, as the perception that all Divis residents were a threat to the Army became continually reinforced. Militant IRA activity, which threatened residents' 
security, meant a corollary loss in support for the republican movement.

In November of 1973 17-year-old Michael Hutchinson was shot dead by a patrol unit at Divis Flats when he fled the scene of a pipe bomb incident. Around the same time the killing of two local Catholic postmen in Divis Street by Loyalist assassins resulted in heightened feelings of fear and mistrust within the Divis community. At this time it became very difficult for Catholics to differentiate between the threats of loyalists and those of the military. Catholics continued to rally around the republican movement in an attempt to ensure security, but while they were largely disillusioned by the physical chaos of the proceeding months they were simultaneously being marginalized from the political process (the only other means of resolution).

In December of 1973, the landmark Sunningdale Agreement was signed between the British and Irish governments. Unfortunately, politicians from the north, including even those of the more moderate Nationalist SDLP and Unionist UDP, were absent from the talks. An agreement was hammered out making the Council of Ireland a fourteen-member body responsible mainly for economic and social matters. In return, the Irish government agreed to recognize the right of the majority in Northern Ireland to remain part of the United Kingdom for as long as they wished. Britain undertook to review internment and release more prisoners by Christmas, and to make the RUC more acceptable to Catholics. The Irish agreed to intensify the offensive against the Provisionals." 20

It seemed, for a time at least, that the violence in Northern Ireland would end. By December of 1973, 75 loyalists and over 500 republicans had been interned without trial. In the immediate wake of Sunningdale there was only one sectarian murder in Belfast. Unfortunately the peace was short-lived, and by February of 1974 there was heavy rioting and sniper fire at the Divis flats in continued reaction to internment without trial. That month, a pipe bomb in a stairwell intended for a patrol unit accidentally injured 11 residents. Faith in the political process was further compromised when the power-sharing agreement fell apart in May of 1974, under pressure from a Unionist Workers Coalition strike. The UWC, aided by the UDA, essentially shut down the state, including factories, shops and a power plant near Larne, in protest of the power-sharing executive. On May 17 the Ulster Volunteer Force sent four cars packed full of explosives to Dublin. Thirty-three people died, making that day the single bloodiest in the history of the Troubles. Soon after, the Secretary of State for Northern Ireland, William Faulkner, resigned, and power sharing collapsed, along with the Catholic minority's faith in the political process.

In September and October of 1974, violence again erupted when 11 Catholics were killed by loyalist paramilitaries, including two young men, Eric Morgan and Michael Loughran, who were shot on the corner of Northumberland Street near Divis Flats. Then, in March of 1975, a schoolteacher who lived at the Divis Flats, John Connolly, was stabbed to death in East Belfast. The result of this sudden increase in violence was the emergence of the Irish National Liberation Army and 


\section{Divis Flats}

its political wing the Irish National Socialist Party (IRSP), who, much like the Provisionals, had become disillusioned by the failing rhetoric of the Official IRA, and preferred to focus instead on the armed struggle. During an ensuing feud at the Divis Flats between the INLA and the "Sticks," as the Officials were called, two men were killed. Eventually, Divis came to be known as an INLA stronghold, commonly referred to as "Planet of the Urps," a colloquialism for the IRSP.

In August, the anniversary of the introduction of internment was marked by massive demonstrations and rioting at Divis Flats. Loyalists from the Shankill clashed with the demonstrating nationalists, and the Army was once again forced to intervene. Unfortunately, after the INLA joined the army in returning fire, and the loyalists subsequently withdrew, the army began engaging with the republican gunmen. Three republicans were wounded, and Jeffery Sluka notes that it was the first action taken against the British army by the newly formed INLA. ${ }^{21}$ This series of events typifies the confusion of guerilla warfare. The Army had been rightly protecting Divis residents from a mob, but the intervention of the INLA complicated the situation, putting residents in further harm's way. Sluka explains, "the IRA later claimed to have defended the community from a joint attack by the British army and loyalist paramilitary groups." 22

Because the success of Irish Republicanism depends entirely on their ability to hide within the general population, innocent Catholics often paid the price, like 10-year-old Stephen Geddis, who was killed when a plastic bullet fired by a soldier hit him in the head during a small riot in the complex that August, 1975. It is interesting to note that the paramilitaries depended on the protection of the community as much (if not more than) the community depended on them. "Our Volunteers operating in Nationalist areas are like fish in friendly waters and it is this close relationship between the IRA and the people that dogs all counterinsurgency attempts at defeating us," wrote one IRA spokesman. ${ }^{23}$ It would seem that the Divis community was willing to accept the presence of the INLA because they felt that in the end they did more to protect residents than they did to harm them; however, this perception was often supported by INLA and IRA propaganda. Perhaps the paramilitaries used their role in community policing to ultimately gain support for their military action? In the early 1990s, Chicago's Black Kings gang made attempts to "better the community" at the Robert Taylor Homes, serving their economic interests and gaining them favor within the project. ${ }^{24}$

The IRA propaganda machine was greatly fueled by the 1976 Prevention of Terrorism Act, which effectively took away the government's classification of political prisoners. Until this point prisoners had been allowed to wear their own clothes, were held in units away from the general prison population, and were granted frequent visitations and access to lawyers once convicted of a crime. In the long run this tactic by the British government, meant to discredit paramilitaries, actually became a propaganda victory for the republican movement. Kieran Nugent and others began the Blanket, or "Dirty" protests, refusing to wash themselves or 
wear the prison uniforms of common criminals.

The immediate effect of internment, coupled with the strict new Prevention of Terrorism Act was that the IRA and INLA significantly reduced their military operations from 1976 to 1981 . This reduction in violence opened the way for alternative means of resolution. In August of 1976 the non-violent Women's Peace Movement, started by Nobel Peace Prize winners Mairead Corrigan and Betty Williams, united Catholics and Protestants. The group, which was started after Corrigan's sister and her young children were killed on the Falls road by a car whose driver had been shot by a soldier, later became known as the Peace People. Its rallies consistently attracted up to 20,000 people, and gave Divis residents an alternative to violence and hope for the future.

The decline in support for militancy can be seen as proportional to a community's trust in the political process and sense of social inclusion, and 1976 turned out to be a year of renewed faith. In September, Secretary of State Roy Mason declared, "unemployment, little new investment, too many businesses closing down, these are the questions that must receive priority," recognizing that economic hardship was a root cause of the ongoing conflict. ${ }^{25}$ This admission led to the introduction of the Fair Employment Act in December of 1976. However, discrimination and inequities in housing conditions remained largely unaddressed by the government.

As paramilitaries struggled to regain control, most of the violence of 1977 came about because of internal feuds between the UDA and UVF and the Officials and Provisionals. September of 1977 was the first month since 1968 that there were no civilian casualties in Northern Ireland. This reduction in violence is also attributable to the new Emergency Protections Act, which sought to:

Provide a system for the arrest, prosecution and imprisonment of those suspected of involvement in terrorist activity, and as a replacement for internment without trial, which did so much to alienate the Catholic population between 1971 and $1975 .^{26}$

The Provisionals had regrouped by December 1978, beginning a massive bombing campaign. However, by this time the UDA and UVF had started to refrain from their reactionary practices of targeting Catholics after every IRA attack. The UDA's chairman, Andy Tyrie, explained that this was because, "the organization no longer targeted ordinary Catholics, but was more selective." 27 This action, along with the February 1979 conviction of 11 of the Shankill Butchers for 19 murders, meant a consequent reduction in support for the IRA and INLA, as the Catholic community began to feel less terrorized. Support for republicanism hit a low point after the August 27, 1979 assassination of the Queen's cousin, Lord Mountbatten and his young nephew, on a boat off the western coast of Ireland. Following the 


\section{Divis Flats}

international recession of 1979, the economy in Northern Ireland had seriously deteriorated, and unemployment levels skyrocketed as a result of the Thatcher government's cuts in welfare expenditure. This meant that, at least temporarily, most residents in west Belfast were more preoccupied with job security than physical security. The Provisional IRA did not regain its position in the Catholic community until late in 1980, when the Blanket Protests gained media attention and there was resurgence in republican sentiment.

In March of 1981, a young Falls Road republican prisoner named Bobby Sands declared that he would go on a hunger strike to protest the loss of political prisoner status. The charismatic Sands was elected to the British Parliament before his death on May 5, 1981. His funeral was attended by over 100,000 people, and Sands became the single biggest martyr for the republican community. ${ }^{28}$ Nine other IRA and INLA men lost their lives during the hunger strike, and after the deaths of every single striker, rioting erupted at Divis Flats. On May 12, only hours after the death of IRA volunteer Francis Hughes, INLA member Emmanual McLarnon fired on British troops in Divis flats and was killed by return fire from Divis Tower. Interestingly, the hunger strike rioting and bonfires were condemned by the IRA because they were seen as being destructive to the Catholic community. A leaflet was distributed around Divis flats, which read:

\section{Irish Republican Army Belfast Brigade}

We have been approached in recent days by local residents of the Divis Flats about the rioting going on in the area. To avoid any confusion or misunderstanding, we wish to make our position crystal clear in respect of rioting. We are not opposed to street conflict directed at the Brits or RUC provided it is organized, disciplined, creates the minimum amount of incon-venience [sic] to local residents and inflicts physical casualties or propaganda defeats on the British forces.

Recent rioting in Divis Flats has fulfilled none of the above criteria. It has been sporadic, undisciplined, has inflicted no physical casualties on the Brits or RUC and has only placed greater hardship on the residents of the flats. Moreover, we have seen how the RUC have been attempting to use the situation - a situation which they encourage to their advantage by trying to improve their image and convince people that they are what they are obviously not, i.e. a police force.

The hijacking of private vehicles, the 
destruction of personal property, and the hardship suffered by the residents are totally unacceptable to us. We have made it clear to young people involved that, if caught, they will be punished. We are aware that there is a group in the flats actively encouraging this rioting for personal gain and we intend to inflict the severest punishment we can on them.

To this end we would appeal to local residents to give us their complete support. In the past some residents, a tiny minority, have obstructed Volunteers in the course of taking action against the hoods. If we are to successfully deal with this situation we need your complete support. Given that, we shall certainly do all in our power to overcome this problem.

Belfast Brigade ${ }^{29}$

This letter clearly reflects the IRA's dual role in community policing and politically motivated militancy. Unfortunately, many young people at Divis Flats felt that they were contributing to the political struggle by rioting, and many others saw events like the Hunger Strikes as an excuse to express their social frustrations and resentment.

At this period in time over 30 percent of Divis residents actively supported Sinn Fein, while an additional seven percent favored the IRSP. 32 percent of the population was opposed to violence as a way of achieving political goals, with 28 percent of those people supporting the moderate nationalist SDLP. However, it is interesting to note that an additional 30 percent of the population supported no party at all. ${ }^{30}$

The public outrage and political currency of May 1981 eventually deteriorated, and from 1982 to 1986 there was, yet again, another reduction in support for republican paramilitaries. The phenomenon of "supergrasses," who were high-level informants, resulted in the convictions of over 50 members of the IRA and INLA, including INLA leader Gerard Steenson in 1982. Most of these convictions were overturned by 1986 , but the temporary result was that only a handful of active IRA men remained on the Falls road.

At the same time, a group of disillusioned residents in Divis Flats were forming both the Divis Residents'Association and the Divis Demolition Committee. While the Residents' Association attempted to raise public awareness through publications and studies, the Demolition Committee took a more militant approach, closing up vacant apartments with cinderblocks, and calling for the demolition of the entire complex. The Northern Ireland Housing Executive brought in a number of architects to assess the conditions of Divis Flats, and the end result was the demolition of Whitehall, Farset, Pound, St. Brendan's and part of Cullingtree block. Interestingly, Pound and St. Brendan's were found to be in the worst condition, 


\section{Divis Flats}

but because Whitehall and Cullingtree interfered with the government's proposed M1 highway, and Farset was difficult to monitor from the top of Divis Tower, those structures were also scheduled for demolition. Regardless of the ulterior motivations of the Housing Executive and Department of the Environment, these initial demolitions were perceived as a victory for the residents of Divis.

Yet another political victory was the Nov 15, 1985, signing of the AngloIrish agreement. Article 1 states that the two governments "affirm that any change in the status of Northern Ireland would only come about with the consent of a majority of the people of Northern Ireland." ${ }^{31}$ This left open the possibility of a future united Ireland, as birth rates among Catholics have always outnumbered Protestants. Loyalists felt largely betrayed by the British government's willingness to compromise. However, they were somewhat reassured by the political climate of the United States, where President Reagan, a close ally of Margaret Thatcher's and proponent of her free-market economic plan, "relentlessly hounded IRA supporters in the United States and initiated a series of extradition hearings against IRA men who had fled to the U.S." 32

On November 8, 1987, the IRA and Sinn Fein took a massive blow, losing much public support when a bomb in the northern town of Enniskillen killed 11 civilians. A year later, in December of 1988, the Fair Employment Bill was reintroduced, after British government figures report unemployment of Catholic men at twice the rate of Protestant men. However, in the previous 10 years unemployment across all demographics had risen from 5.7 percent to 18.3 percent, and issues of job security continued to overshadow political frustration in Northern Ireland until the early 1990s. ${ }^{33}$ Commenting on the persistent poverty at the complex and its connections to crime, Sluka wrties,

Divis Flats is known for the high level of antisocial behaviour among its young people, but is this the result of a breakdown in respect for law and order resulting from the troubles, or is it the result of the fact that young people living in the complex are poor, bored, and frustrated both by their social, economic, and housing conditions, and by the bleakness of their prospects for the future ${ }^{34}$

Despite October of 1993 being the bloodiest month of the Troubles since 1976, during which time 27 civilians died, and for the first time loyalists killed more people than republicans, the future for most Catholics in West Belfast began to look a little more promising. During the summer of 1993 the remaining eight blocks of Divis Flats were finally demolished. For many, this physical act symbolized a step toward greater social equality for Catholics, as residents would be re-housed in new row and terrace structures. It also represented the elimination of perceived 
repression by the British government, with residents essentially set free from their psychological prisons.

Also in the summer of 1993, Sinn Fein leader Gerry Adams and SDLP leader John Hume began meeting together regularly to discuss a united nationalist agenda. In December of that year, while the IRA held its cease-fire, they both participated in the signing of the Downing Street Declaration, which reinstated the power-sharing executive. Many Loyalists were outraged by this compromise and retaliated by killing Catholics, but the Provisional IRA had become at least temporarily marginalized by the success of its political party. The decline in republican violence can be attributed to both a renewed faith in political participation, and the increased feelings of social inclusion that resulted from the demolition of Divis Flats. While the fear of loyalist vengeance remained ever present in 1993, the physical and psychological insecurities of 2,000 Divis residents became instantaneously eliminated, along with their dependence on the INLA for protection.

Following a brief campaign of bombing, in August of the following year the IRA renewed their ceasefire, and Hume and Adams released a joint statement declaring:

A just and lasting peace in Ireland will only be achieved if it is based on democratic principles. It is clear that an internal settlement is not a solution... If a lasting settlement is to be found there must be fundamental and thorough-going change, based on the right of the Irish people as a whole to national self-determination. ${ }^{35}$

In acknowledgement of the achievements of these two men, on November 30, 1995, Bill Clinton became the first serving U.S. President to visit Northern Ireland. For Northern Ireland's nationalist community his presence contributed to even greater hope for a political, not armed solution.

However, while the militancy of the IRA was effectively suspended, their role as community police continued to be necessary if peace and security were to be maintained in West Belfast. So, by 1995 an organization called Direct Action Against Drugs emerged, and on December 19 of that year they killed an alleged drug dealer on the Ormeau Road. The RUC identified the killings of five dealers that year, but identified the IRA as responsible, not Direct Action, severely compromising Sinn Fein's position in continued peace talks. Gerry Adams and Sinn Fein managed to control the Provisionals for a while, but in February of 1996 a $500 \mathrm{lb}$ bomb

detonated at London's Canary Wharf commercial district announced the end of the IRA ceasefire. Then, in July and August (the loyalist marching season), rioting in Protestant communities erupted as the RUC attempted to blockade an Orange march on Portadown's Garvaghy road in County Armagh. Similar triumphant parades 


\section{Divis Flats}

attempted to pass through Catholic neighborhoods in West Belfast. Rioting ensued and as security became compromised the Provisionals, who had been harshly criticized for the Canary Wharf bomb, again began to gain community support.

On May 1, 1997 Britain's Labour party won a landslide victory, and in Northern Ireland Sinn Fein won a record 16 percent of the vote. David Trimble's Ulster Unionist Party maintained the overall majority, with 32 percent, and Hume's SDLP brought in 24 percent. The radically anti-Catholic Reverend Ian Paisley's Democratic Ulster Party trailed with 13 percent of the vote.

This victory for Labour meant the appointment of Mo Mowlam (who received her Ph.D. from The University of Iowa in 1977) as the new Secretary of State for Northern Ireland. The perceived victory for nationalism was followed by a new Provisional ceasefire in the summer of 1997, and while the INLA and the new "Continuity" IRA remained militant, Sinn Fein was once again allowed to participate in peace talks. Their participation was temporarily suspended in February of 1998 when another alleged drug dealer named Brendan Campbell was murdered by Direct Action on the Lisburn road. However, by April of that year all parties signed onto the Good Friday Agreement (or Belfast Agreement, depending on ones' political orientation), which reaffirmed the Downing Street Declaration, reinstated the Northern Ireland Assembly, and called for an unconditional IRA disarmament in exchange for the release of political prisoners. In a public referendum 70 percent of the population endorsed the Good Friday Agreement, and while the UDA refused to sign on due to pressure from the frustrated Orange Order, the UFF did agree to it because of their own prisoner concessions.

Now that the devolution of the Provisional IRA was ensured, a select group of persistent militants broke away, forming the "Real" IRA. On August 15, 1998, they detonated a bomb in Omagh, killing 28 innocent civilians and injuring 360. As the single largest loss of life of the entire Troubles, the public outcry to this tragedy meant the subsequent suspension of the Real IRA's military operations by September 8. They claimed to have called in multiple warnings, but there was no way for the group to survive once they had alienated the nationalist community. One week after the Omagh bombing the INLA also announced its cease-fire, stating:

We acknowledge and admit faults and grievous errors in our prosecution of the war. Innocent people were killed and injured and at times our actions as a liberation army fell far short of what they should have been. For this we as republicans, as socialists and as revolutionaries do offer a sincere, heartfelt and genuine apology. It was never our intention, desire or wish to become embroiled in sectarian or internecine warfare. We have however nothing to apologise for in taking the war to the British and 
their loyalist henchmen. Those who preyed on the blood of nationalists paid a heavy price. However the will of the Irish people is clear. It is now time to silence the guns and allow the working classes the time and opportunity to advance their demands and their needs. ${ }^{36}$

In the wake of the Good Friday Agreement, the issue of decommissioning remained the most troublesome for the people of Northern Ireland. Recent polls show that 93 percent of Protestants and 68 percent of Catholics favor immediate paramilitary decommissioning. Despite the outcries of Unionists on slow IRA decommissioning, Good Friday has remained largely successful. In one of the most visible changes to Northern Ireland, the RUC was replaced by the Police Service of Northern Ireland (PSNI) on November 3, 2001. The aim of the PSNI is to include a proportionate number of Catholics in the service, reducing negative perceptions and ensuring equal treatment. By July of 2005 the IRA was declared fully disarmed, but unfortunately violence in Northern Ireland has not ended. With the absence of the IRA and an increase in perceived threat to Protestant supremacy, loyalist paramilitaries have recently feuded over territory and drugs. July remains an especially tenuous time of year in Belfast, as Orangemen attempt to hold annual parades through Catholic districts, however the Falls Road community remains largely hopeful. In August of 2005 their calls for the "demilitarization" of Divis Tower were finally answered, as the British Army dismantled their outpost on the top two floors in recognition of IRA disarming. This symbolic gesture was as important as the demolition of the Divis Flats in 1993, and ironically meant an increase in feelings of security for Falls residents.

This chapter has provided an overview of the conflict in Northern Ireland since 1968 and has put the insecurities of Divis Flats residents in context. The intention was to discuss not only the IRA and INLA's vital role in community policing and protection, but to show that the fears of Catholics on Belfast's Falls Road were both a factor of everyday life and necessitated the presence of paramilitaries. Turning toward the particular issue of architectural design, the next chapters discuss ways in which the built environment contributes to feelings of insecurity. An in-depth examination of physical and psychological threats to Divis residents further supports the argument that thoughtless design has contributed to civil conflict in Northern Ireland.

\section{Post-Modern Interpretations of Community Security: The Work of Jane Jacobs and Oscar Newman}

According to psychologist Abraham Maslow's Hierarchy of Needs, developed in the 1940s and 1950s, basic physiological requirements such as food 


\section{Divis Flats}

and shelter lie at the foundation of human needs. These are followed next by the need for physical security. Maslow notes that adults have little awareness of their security needs except in times of emergency or periods of disorganization in the social structure (such as widespread rioting), and that children more acutely display the signs of insecurity and the need to be safe. Tertiary needs include those for love and a sense of belonging, as well as requirements for self-esteem, and finally selfactualization. ${ }^{37}$

Within the context of the conflict in Northern Ireland, this hierarchy helps to explain why those whose primary needs have not been fulfilled have little time to worry about political or national allegiance. This hierarchy also helps to explain why issues of housing and safety are so fundamental in understanding an individual's motivation to support armed conflict.

The work of postmodern theorists Jane Jacobs and Oscar Newman both single out the need for security in urban contexts. The two differ only in the way in which they seek solutions to insecurity; Jacobs focuses on the role that a community's citizens play in indirectly deterring crime, while Newman focuses on the aspects of specific physical design that directly dictate safety. Both physical structures and the people who inhabit them have been shown to have reformative powers in a public housing complex. However, this realization also means that poor architectural design, which discourages community relationships and eliminates physical boundaries, can also result in increased rates of crime and feelings of isolation, as was the case at the Divis Flats in Belfast.

The fundamental role that feelings of insecurity have played in perpetuating the conflict in Northern Ireland cannot be underestimated. In a survey conducted by the Northern Ireland Housing Executive just before the signing of the Good Friday Agreement in 1998 and the subsequent Provisional IRA ceasefire, a list of social problems facing the region were given different rankings according to the religion of the respondent. Overall, Protestants regarded the "Troubles" as the most serious problem facing the people of Northern Ireland, followed by unemployment and the high cost of living. Catholic respondents, however, regarded low wages as the most serious problem, followed by unemployment and the high cost of living. For Catholics, the politics of the "Troubles" came only fourth in order of seriousness. ${ }^{38}$

While the survey did break a number of responses down according to religion, in an obvious attempt to demonstrate equality, they did not accordingly address proportions of owner-occupiers versus Housing Executive tenants. However, a majority of owner-occupiers regarded the "Troubles" as the most serious problem facing Northern Ireland, followed by unemployment and low wages. Housing Executive tenants overwhelmingly named the high cost of living, low wages and unemployment as their biggest challenges. These statistics are most important in light of the fact that a majority of owner-occupiers are Protestants, and a proportional majority of Housing Executive tenants are Catholics. Such 
findings also support the argument that in order to have concern over politics, the fundamental needs for physical security, i.e. housing, must first be met. Only after abject poverty is addressed can one truly focus on issues of politics and nationality, or "self-actualization."

Thus, for a majority of poor Catholics in West Belfast who are simply struggling to provide for their families, a roof over ones' head and food in ones' stomach is a much more significant issue than national allegiance. Physical conflict has been concentrated in the poorer areas of the city, but it is those who own houses in outlying suburbs like Holywood and Newtownards who are most concerned with the political situation. What, then, explains the clashes between working classes on the Falls and Shankill Roads since 1969? The answer lies in the fact that they are in direct competition for both jobs and housing.

If the need for security must be met before politics can be questioned, then it is all the more appropriate to address issues of housing in Belfast when attempting to explain the root causes of the Troubles. Specifically, how did a lack of security for the residents of Divis Flats create conflict? The answer is not linear, but is compounded by many factors, including the need for community policing by the IRA and INLA and the subsequent alienation of the British Army from Divis residents.

Jane Jacobs, who wrote a number of works including The Economy of Cities, Cities and the Wealth of Nations, and The Nature of Economies, is perhaps best known for her 1961 book The Death and Life of Great American Cities. It was revolutionary in its critique of modernism, and came about principally as a reaction to urban-slum clearance programs of the 1950s that were very much inspired by the work of men like Le Corbusier. Jacobs saw an organic and spontaneous nature of America's urban landscapes being dominated by corporate and government interests at the expense of the average citizen. She sought to explore the original context of the city in order to show the largely unappreciated nuances and personal interactions which made it a far more hospitable place than the uniform and impersonal concrete high-rises that had become so popular. In describing her street in New York's East Village, Jacobs notes that,

The safety of the street works best, most casually, and with least frequent taint of hostility or suspicion precisely where people are using and most enjoying the city streets voluntarily and are least conscious, normally, that they are policing. The basic requisite for such surveillance is a substantial quantity of stores and other public places." 39

These same observations on a community's innate security could be easily applied to any urban context, particularly in Europe, where cities have been evolving 


\section{Divis Flats}

organically for hundreds of years. In Belfast, for example, the former Pound Loney community, located just off of the lower Falls Road, was known as a safe and closely knit neighborhood, where mothers looked after each others' children from kitchen windows, and residents lived out their entire lives. Granted, the mid- $19^{\text {th }}$ century two up-two down hovels in the Pound Loney lacked many convenient amenities like running water and central heating (which were later offered at the Divis Flats), but the greater community had a abundance of the more significant social services, like pubs, shops and corner markets. Jacobs notes that these kinds of amenities fill city streets and inadvertently deter crime in the process. Regarding the necessity of this security for a healthy community, she explains that:

The bedrock attribute of a successful city district is that a person must feel personally safe and secure on the street among all these strangers. He must not feel automatically menaced by them. A city district that fails in this respect also does badly in other ways and lays up for itself, and for its city at large, mountain on mountain of trouble. ${ }^{40}$

What happens then, when a community is denied the kinds of amenities that fill its public spaces? At the Divis Flats one can see that serious problems with crime, vandalism and drug abuse quickly emerged, as residents hid in the seclusion of their anonymous flats, fearful of the vast open spaces below them.

The effects that persistent fear has on a community, and especially its children, are numerous, and included a disinterest in school or employment, depression, anxiety, substance abuse, and social exclusion. However, a common mistake in the examination of conflict in Northern Ireland is to place blame only on the paramilitaries, or "terrorists," and to fail to recognize that the British army was, in fact, the perceived enemy of a majority of Catholics. This misconception is the product of 35 years of bias on the part the media and the British government. While it does help to identify the effects of persistent violence on a community, it also exposes a misunderstanding of the complexities of the Troubles. In his 1977 book Terrorism, author Robert Liston identified a condition called the "Belfast Syndrome." He explained that:

Terrorism is now recognized as a cause of illness. Doctors in Northern Ireland report an increase in patients suffering from what they call the Belfast Syndrome. The patients, usually women and children, cry and tremble uncontrollably. Often they can't remember their names or where they live. Sometimes they are unable to speak. Doctors 
usually prescribe tranquillizers and mild sedatives, but patients do not always respond to such treatment. The Belfast syndrome is believed to be the result of living with constant terror, where the enemy is not easily identifiable and the violence in indiscriminate and arbitrary. ${ }^{41}$

While this work does help to identify the effects of persistent violence on a community, it also expresses a clearly one-sided interpretation of the Troubles.

The children who grew up in Divis Flats were exposed to violence on a regular basis, becoming desensitized to it and accepting it as a way of life. These children, who were mostly unsupervised as they ran through the dirty terraces and dark stairwells of the complex, were quickly recruited into joyriding, theft, vandalism and drug abuse. Such internal crime perpetuated the need for paramilitaries, and further encouraged the presence of the British Army. The residents of Divis Flats, who sought a safe-haven from Protestant mobs and paramilitaries after the rioting of 1969, became prisoners within their own complex. Ultimately, the structure did not alleviate fear, but encouraged it. One Divis resident wrote, in a collection of short stories entitled No Place for a Dog, that:

A whole new generation of children have been reared in these grey concrete blocks - kids who don't know what it is like not to have armed soldiers on the streets, plastic bullets, violence and death. If they are a tougher breed than us, should we criticize? After all, these kids have had to be tough. ${ }^{42}$

The people of Divis Flats had to be tough because their physical environment provided them no safe haven. In a comparison study with Catholic children from the neighboring terraced house Twinbrook estate, children at Divis Flats were shown to have significantly higher rates of emotional distress. A shocking 1987 study released by faculty at the University of Ulster showed that while nine percent of Divis children were "affected by depression or weeping so cannot face school or mix with others," less than one percent of children at Twinbrook had similar problems. ${ }^{43}$ In West Belfast, persistent poverty and feelings of insecurity can easily lead to social exclusion. According the Green Paper on housing, published in 2000 by the British Department of the Environment, Transport and Regions:

Social exclusion can be exacerbated by crime and fear of crime and can be worsened by housing which lacks adequate security. . .the effect of high crime rates is to undermine communities, create unpopular 


\section{Divis Flats}

neighborhoods and reinforce social exclusion. ${ }^{44}$

While 14 percent of children at Divis were "affected by loss of appetite," only one percent of those at Twinbrook were affected. ${ }^{45}$ The Catholic children involved in this study came from similar backgrounds, with similar levels of poverty. The only differentiating factor between the two groups was their physical environment.

That environment is effected by what Oscar Newman called "defensible space," in both his 1972 and 1997 books, published by the U.S. Department of Housing and Urban Development. In the more recent study he writes that:

Defensible space is a surrogate term for the range of mechanisms - real and symbolic barriers, strongly defined areas of influence, and improved opportunities for surveillance - that combine to bring an environment under the control of its residents. ${ }^{46}$

In relation to the Divis Flats area and the Lower Falls road, there are, today, an abundance of barriers, areas of influence, and opportunities for surveillance, fostering feelings of security, even for strangers. For example, a shopping center located on the corner of Northumberland Street and the Falls Road sits next to the Cupar Street wall. There is no longer an army checkpoint at the wall, but it remains a reassuring part of the landscape for both Falls and Shankill residents. The entire parking lot of the shopping center is surrounded by bars of vertical fencing, but is left open during business hours. Across the street from this is the Provisional IRA's Memorial Garden. It is a small, well-landscaped and maintained sanctuary on the main thoroughfare, but is also surrounded by a fence and tall shrubs. Much like the rest of Great Britain, everywhere in Belfast is monitored by closed circuit television.

One would think that in an apartment complex under constant surveillance by the British Army, where the entry to every single apartment can be seen from the top of the tower, security would be ensured. But in fact, because soldiers were perceived as the enemy of residents at the Divis Flats, and residents were all perceived as republican sympathizers by the army, feelings of security were very much compromised by the architectural design. Furthermore, because other districts of Belfast were not under direct supervision by the army (only CCTV), with helicopters constantly flying over and landing on the tower, the residents of Divis Flats began to feel uniquely criminalized. It is also important to note that while the army was provided with opportunities for surveillance through the physical design of the Divis Flats, residents were denied equal supervision of their children in the courtyards below.

In addition to "the capacity of physical design to provide surveillance opportunities," Newman identifies three other characteristics of defensible space. 
These include, "the capacity of design to influence the perception of a project's uniqueness, isolation and stigma," or the effects of social exclusion. Also important are "the influence of geographical juxtaposition with safe zones on the security of adjacent areas," namely physical amenities like a community center or stores. But the single most significant characteristic of a safe environment is its ability to create zones of both real and symbolic territorial influence. ${ }^{47}$ It is perhaps a bit ironic that physical barriers meant to deter intruders can ultimately foster feelings of social inclusion.

Real territory, as discussed, is defined by such design elements as landscaping, limited access halls and lobbies, and fences, all of which were absent from the Divis Flats. However, symbolic barriers are ever present. "In our interviews with public housing tenants, we have found that expressions of territorial feelings correspond strongly with a concern for the maintenance of law and belief in the possibility of its enforcement," he writes. ${ }^{48}$ This need for territorial definition is explained in Jacobs' section on "turf." The role that symbolic barriers play in protecting a community can be very clearly seen on the lower Falls Road. It was these symbols of territoriality that first brought me to the Divis area.

The phenomenon of mural painting in Northern Ireland has been a reflection of territory since it first emerged following the rioting of 1969, and the height of the republican tradition came during the 1981 Hunger Strikes. Murals can be expressions of relative insecurity when they contain images of masked gunmen, ominously standing watch over the street corner. The evolutionary change in republican mural painting, from such paramilitary images to reflections of cultural tolerance and peace today, reflects an overall increase in feelings of security among the Catholic community, and a corresponding decrease in feelings of political and social marginalization. Meanwhile, loyalist murals have continued to display themes of gunmen and fallen militants, as the perceived threat of republicanism has remained, and even increased since 1998's Good Friday Agreement. The result of my adventures walking the streets of West Belfast to photograph murals was a first-hand appreciation of both real and symbolic barriers. As a pedestrian I became hyper-aware of the space around me, and how welcome (or safe) I either did or did not feel in a particular area.

The work of Jane Jacobs in identifying "eyes on the street" as the foundation of a secure community, and the work of Oscar Newman in identifying the physical characteristics that dictate territory, are crucial when examining the security failures of the Divis Flats. A lack of amenities for residents combined with a lack of real territorial barriers to encourage insecurity in an area that was already plagued by poverty and crime. The absence of security for the residents of Divis Flats, largely dictated by the physical environment, resulted in a consequent allegiance to the IRA and INLA as a source of protection. 


\section{Divis Flats}

External Threats to the Residents of Divis Flats:

The British state, Loyalist Paramilitaries, and Republican Politics

Divis was conceived without involving the people who would have to live there. Against the wishes of some of the Loney community. As a quick and thoughtless solution to "slum clearance." By replacing honest information with slick salesmanship. With no regard for the social infrastructure of an established community. To suit the politicians and the profiteers. ${ }^{49}$

- Lower Falls Residents Association, 1975

Because the ultimate goal of this paper is to show that the conflict in Northern Ireland was perpetuated by the insecurity of social conditions at the largest Catholic public housing project, it is necessary to first identify what those conditions were. As mentioned, the Troubles are often explained within the context of political and national allegiance, but how did politics, economics and national identity ultimately affect Catholic society and the residents of Divis Flats? More specifically, how did the external interests of politicians, economists, city planners and the military result in an increase in support for Irish republicanism at this particular public housing complex?

Various attempts by the British government to weed out IRA and INLA members often had the effect of alienating the entire Catholic community. One Divis resident expressed his frustration with the Emergency Protections Act of 1973, explaining that:

The EPA is custom built for the oppression of a people. It's the model legislation for any country that wants to oppress people. The whole conveyor belt system is corrupt. The whole legal system here is geared to politics, not justice. They should stop using the law as a counter-insurgency tool. The EPA isn't a justice system - there's no justice for Catholics here. Here, the law is a tool to keep Catholics under control and in their place..$^{50}$

This lack of faith in government legislation reinforces feelings of political marginalization and corresponds to an increase in support for Republican militancy. If citizens do not feel that social justice can be achieved within the system, then they are forced to work from outside of it. Searching a person's home without warrant, imprisoning and interrogating an individual for a week, initially denying 
them access to legal council, and using evidence gathered during such action against others in the community simply reinforces mistrust in the government.

Furthermore, the intervention of the British army in social programs, specifically city planning and public housing, resulted in even greater skepticism and resentment from the Catholic community. In 1979 a number of newspaper articles exposed the military's direct involvement with the Belfast Development Office and the resultant establishment of a "Security Committee on Housing." This discovery makes sense within the context of the Divis Flats, where the door to every apartment was oriented toward the army post on Divis Tower, and a highly concentrated Catholic population resulted in more efficient government supervision. One urban planner noted that "the subject of police and army involvement in planning has in recent months been the subject of fierce controversy, following a series of 'leaks' from within the DOE." 51

Not only did the military's counter-insurgency efforts benefit from a structure like the Divis Flats, but local politicians did as well, for whom a large Protestant constituency in central Belfast was essential in order to maintain power. In the midst of urban renewal projects, an example of the kind of gerrymandering that was prevalent in Belfast can be seen at the Old Park Redevelopment Area (RDA 42), just to the east of the river Lagan. An internal Housing Executive memo from 12 June 1979 explains that:

The area (RDA 42) suffers sectarian strife. Future real demand from 'orange' will be minimal, while future real demand from 'green' will be maximal. The problem is to proceed to public enquiry, where sectarian issues are likely to be raised since 'redevelopment' will be seen as the replacement of Protestants for more Catholic houses. ${ }^{52}$

Because significant numbers of Protestants were moving to Belfast's more affluent suburbs in the late 1970s, and public housing was being demanded by a greater number of Catholics (for whom unemployment and low wages were greater concerns), the Housing Executive was concerned with a potential shift in demographics. They sought ways to entice Protestants to remain in the inner city, building terraced and row houses in areas like Andersonstown, Sandy Row and the Shankill Road, rather than high-rise structures seen in the Catholic New Lodge and the lower Falls Road.

In addition to the military and political interests of the British government being served by the Divis Flats complex, which helped to concentrate the Catholic population, economic interests were also of great concern. In the early 1960s, slum clearance projects of the Pound Loney district, where Divis was eventually built, coincided with plans to build a massive four-lane highway. The M1 was not 


\title{
Divis Flats
}

completed until the early 1980s, but both the initial structure of Divis Flats, as well as the later demolition of four of its blocks in 1983, made building the highway possible. One city planner asked:

\begin{abstract}
What should Belfast's planners do? Should they use their position and skills to try to provide the physical form appropriate to a harmonious society? Or should they accept the existence of fear and hatred between Protestants and Catholics, and the active presence of the army and police, and merely do what they can to accommodate a state of permanent tension? If the latter, will they not be helping the ensure that Belfast will ever be at peace with itself? ${ }^{53}$
\end{abstract}

I do not wish to demonize city planners and the Northern Ireland Housing Executive. Their efforts at deterring civil conflict through the built environment (i.e. the building of the Peace Line) have been commendable, providing much needed security to both the Protestant and Catholic communities. Indeed, Belfast has become one of the most important locales for the study of urban and regional planning. However, the realities of economic, political and military influence cannot be ignored, nor can their effects on the psyche of Belfast's minority population.

It would be wrong to suggest that all of the politicians, city planners, and architects involved in projects like the Divis Flats had malicious intentions. The results of their efforts may, in hindsight, appear disastrous. However, many of the decision-makers were well intentioned and, at the time, believed strongly in the socially reformative power of modern housing. Indeed most former residents of the Pound Loney didn't have internal plumbing or central heating. Unfortunately the process of urban redevelopment often involves decisions which may initially appear to be practical solutions (i.e. high-rise structures which allow for open space, or the use of asbestos sheeting to insulate concrete walls) but over time can cause serious problems.

Architects and planners did not foresee the social stigmas associated with such structures either, yet these realities must be considered in hindsight when examining threats to the well-being of Divis residents. It was often the case that residents of Divis Flats would list the address of a friend or relative when applying for a job, because the flats had such a notorious reputation throughout Belfast. The very physical nature of industrial modern housing is a contradiction to established notions of domesticity and individuality. Feelings of social exclusion were common in such impersonal, disconnected high-rise structures. "Social exclusion through housing happens if the effect of housing processes is to deny certain social groups control over their daily lives, or to impair enjoyment of wider citizenship rights," explains one sociologist. ${ }^{54}$ 
In 1997 Tony Blair's Labour government established a special Social Exclusion Unit (SEU) to combat a series of contributing factors to what they perceived as a growing epidemic. The SEU defined social exclusion as, "a shorthand term for what can happen when people or areas suffer from a combination of linked problems such as unemployment, poor skills, low incomes, poor housing, high crime environments, bad health and family breakdown." 55 At least in the case of the Divis Flats, poor housing conditions were the primary cause of high crime rates, bad health and family breakdown.

Regarding the military's direct role as an external threat to the lower Falls community, it is worth repeating that there were initially no feelings of antagonism. The soldiers were perceived as protectors. However, following a series of riots during which many bystanders, including children, were injured or killed with plastic bullets, the Divis Community's perception of the army became tragically altered and support for republican paramilitaries consequently grew.

The spring and summer of 1981 were especially traumatic times for residents due to Hunger Strike rioting and protests. In May, a four-year-old was struck in the head with a plastic bullet after he and his friends had been throwing stones at an armored patrol unit. That same month, twelve-year-old Carol Ann Kelly was killed on the Falls Road by a plastic bullet. "The use of plastic bullets has produced a great deal of Catholic resentment against security forces and the government, and has increased support for the IRA and INLA," observed Sluka, who was living and conducting research at Divis Flats during this time. ${ }^{56}$ The British Army's plastic bullets proved fatal not only to young children. In July of 1981 Peter Doherty was killed at Divis Flats when a plastic bullet came through his kitchen window and hit him directly in the head.

In addition to plastic bullets, unwarranted searches at the flats (allowed under the Prevention of Terrorism Act in 1976 and the Emergency Protections Act the year later), did much to alienate Divis residents. Feelings of personal insecurity increased when residents felt the sanctity of their most private spaces violated by groups of soldiers who had little regard for their personal property. In regard to an increase in support for the republican movement after the hunger strikes, Sluka writes,

What they [the British government] have either failed to learn or do not care about is that they have to control the everyday acts of harassment and abuse by individual soldiers on the ground that do as much in the long run to alienate public opinion as larger actions. ${ }^{57}$

Another scholar notes that, "offensive and aggressive British activity... had the effect on the community of tilting the balance of allegiance toward the Provisionals." 58 


\section{Divis Flats}

It is important to mention that there is an inverse relationship between community support for the British army and support for the IRA. The initially positive perception of the army declined when it became clear that their role was not to protect the residents, but rather to monitor and control them. Simultaneously, support for republican paramilitaries steadily increased in the early 1980s as Divis residents became more politically disillusioned and more physically threatened. At Chicago's Robert Taylor Homes, a complex of 28 16-story high-rises, "tougher law enforcement strategies produced growing distrust between the police and a tenant body" during the 1980s. ${ }^{59}$ Just as the Prevention of Terrorism Act and Emergency Provisions acts of the late 1970s were used to infiltrate the Divis Community to weed out militants, at the Taylor Homes "tenants complained that police were using the mob action aimed at gang members to arrest non-gang-affiliated youth, from whom they hoped to obtain information on criminal activities." ${ }^{\prime \prime}$ This strategy of interrogation is one of the reasons that the IRA took such strong action against petty crime and was so committed to community policing; they saw the potential for lowlevel informants who had been brought in on non-political charges. The general hostility toward law enforcement felt at the Divis Flats (the natural product of an "us versus them" mentality) was also seen at St. Louis's Pruitt-Igoe complex in the late 1960s. Oscar Newman explained:

In the high-rise project - a labyrinth profusion of corridors, fire stairs, exits - police report great difficulty in locating apartments, to say nothing of pursuing criminals. Officers responding to calls meet tenant indifference if not open hostility. It is not uncommon for tenants to angrily attempt to drive off police responding with well-intentioned assistance. Tenants are skeptical of police effectiveness and fearful of police officers and of police intentions. ${ }^{61}$

However, unlike in Northern Ireland, when discussing American minorities' mistrust of law enforcement, politics are not regarded as a contributing factor. Rather, it is the economic and social inequities of society that are acknowledged as both fostering crime and simultaneously marginalizing the minority group. When communities become plagued by crime, but do not see the police or army as allies, what becomes their alternative? At the Taylor Homes, informal "Mama's mafias" became the initial solution, and community groups eventually formed. When the residents of Divis Flats in Belfast became plagued by a persistent lack of security, and the presence of the British army actually contributed their fears, they were slow to organize formally. Instead, they sought protection from the IRA and INLA.

Before the military threat of arrest, harassment and being shot by unaccounted-for plastic bullets emerged, the residents of Divis Flats were fearful 
of their neighboring loyalist community. As mentioned, it was the burning and rioting of August 1969 that resulted in a mass exodus of Catholics to the safety of Divis Flats, and which was instigated primarily by Protestants from the Shankill road. Falls resident Kathleen Magill described her fear on the night of August 15 in a collection of work put out by a writers' group at the Mill. She recalls:

I watched in sheer terror as one man was pointing out the Catholic houses while the others threw petrol bombs into them, the street was blazing like a furnace. All around me I could hear the sound of breaking glass and the screams of terrified women and children. ${ }^{62}$

The burned out houses along what is, today, the largest Peace Line wall, remained vacant and served as a buffer no man's land between the Falls and Shankill communities. In the years following, Catholic fears of the Protestant community only escalated with the forming of loyalist paramilitaries.

The Ulster Defense Association (UDA) was formed in 1971 as a reaction to the post-NICRA resurgence of Irish republicanism. While the Provisional IRA claims to have never targeted Protestant civilians, they did attack Protestants who worked for and served the government, especially RUC officers, soldiers, and the businesses that they frequented. Unfortunately, many innocent bystanders were killed in these attacks, and the UDA's aim was to "protect the community, and to stop the IRA," according to one-time leader John White. ${ }^{63}$ In contrast, in the 1970s and 80s the UDA (as well as the Ulster Freedom Fighters and the Ulster Volunteer Force) perceived any Catholic as a legitimate target following an IRA attack. UVF leader Gusty Spence once remarked that any Catholic was by definition an IRA man. ${ }^{64}$ Unfortunately, this policy of retaliation became all too commonplace as civilians near the Falls Road were abducted and shot at random.

The height of these fears came in 1975 and 1976, when a gang of men later known as the "Shankill Butchers," led by psychopath Lenny Murphy, began grabbing men near the Falls Road and Divis Flats. The main thoroughfare from the Shankill to the Falls, Northumberland Street, is only blocks from the flats. In November of 1975 Murphy and his crew dragged 34-year-old Catholic Francis Crossan into a black taxi, where they proceeded to beat him with a tire iron and drive him to an alley in the Shankill district. There, Murphy proceeded to hack through his neck with a butcher knife. In February 1976 two other Catholics were murdered in similarly gruesome ways. The next month Murphy was taken off the streets on a weapons possession charge, but his gang was instructed to keep killing, and four more young men were butchered over the next several months. The brutality and random nature of these acts traumatized the Falls community, and many were afraid to go out alone or at night in the mid-1970s. These were the 


\section{Divis Flats}

most horrific of crimes, but they demonstrate the very real need for IRA protection from outside threat.

It would be a mistake, however, to blame only the British government and loyalist community for feelings of insecurity at the Divis Flats. In fact, the republican movement itself must share a large proportion of the blame. Granted, the IRA and INLA were active in community policing, and their highly structured system of warnings to petty criminals, followed by suggestions to leave the area, and finally knee-cappings or executions, deterred a significant amount of crime in the poorest areas of West Belfast. But their political and military campaigns did, in the end, much to harm the average Catholic.

The high points in public support for the republicanism typically followed the most violent and repressive actions, including the introduction of internment in 1971, the events of Bloody Sunday in 1972 and the Hunger Strikes of 1981. Conducting research at the Divis flats at the time of the Hunger Strikes, Sluka recalls that:

Youths hijacked and burned over 100 cars, buses, and trucks around the complex, barricaded all of the entrances, and turned Divis into a "no go" area. For six weeks they kept the Security Forces out. Some of the balconies were draped with sheets to block observation from the army post on top of Divis Tower, vigilante patrols were organized, and masked and armed IRA and INLA patrols were seen openly on the walks... During the hunger strike, Divis Flats was undoubtedly one of the most violent locales in Belfast. $^{65}$

Unfortunately, unconstructive mayhem like this only had the effect of further alienating the innocent residents of the flats from the British army. The army came to view every resident as a potential IRA or INLA member, and consideration for the residents' well-being was rarely considered when the troops themselves were worried about getting shot or blown to bits in a stairwell. Additionally, by allowing naïve and frustrated young people to be physically destructive (the aforementioned leaflet passed around by the Belfast Brigade was a rare event), the paramilitaries were, in effect, helping to justify the military presence at Divis which they fought so hard to drive out. Not only did the necessary embedding of the IRA and INLA deep within the general Catholic population justify the presence of the military, it also set the community up to violent attacks from loyalist paramilitaries, like those in 1971, 1975 and 1993.

Furthermore, by not clearly differentiating between the two distinct roles of the paramilitaries, namely the armed struggle for a united Ireland and their 
secondary position as community police, the IRA allowed their entire organization to be discredited by both the government and the media. As discussed, a group called Direct Action Against Drugs was eventually formed in 1995, allowing the Provisionals to suspend their military actions while Sinn Fein participated in peace talks. But even then, their efforts were easily dismissed as those of "terrorists".

The position of Republican paramilitaries can be seen as a quagmire for the residents of Divis Flats and the entire West Belfast nationalist community. The power of militants fed off the frustrations of social inequality and feelings of political marginalization within the community. On the one hand, the IRA and INLA's role as protectors was made necessary by the very real threats of loyalist paramilitaries and local criminals. On the other hand, their political agenda and physical presence resulted in aggressive actions by both loyalists and the British army, which only increased feelings of social exclusion and insecurity.

Internal Threats to the Residents of Divis Flats:

The Physical and Psychological Effects of Architectural Design

In addition to the external threats of the British government's military, political and economic agenda, and the violent actions of loyalist paramilitaries and the IRA, there were numerous internal problems at the Divis Flats which contributed to feelings of insecurity. Among the various failures in architectural design were a general lack of amenities and landscaping, dark stairwells and corridors, the inability to supervise children, an abundance of trash, the failure of elevators, an impractical laundry system, the inability to keep warm, the growth of mold and an increase in ill health. Additionally, the psychological effects of the modern public housing system, including a lack of community, isolation from society, and feelings of general hopelessness and depression, coupled with physical concerns and contributed to support for the IRA and INLA. This final chapter is divided into two sections: the physical deficiencies of the flats and the psychological effects that design had on the community.

\section{Physical Deficiencies}

In 1972 Oscar Newman identified a handful of physical characteristics that reinforced criminal behavior in a housing complex, public or private. These included its size (at least seven floors high and housing over 1,000 families), the destruction of old city blocks to make one "superblock" which is closed to city traffic, and a relatively free composition of apartment blocks on the site with one continuous, undifferentiated green space between structures. Additionally, he added that most of the physically threatening individual buildings are slab or cruciform towers with 150 to 500 families, and that they usually contain one central, interior-facing

lobby with elevators. Newman points out that the single most significant difference 


\section{Divis Flats}

between low and upper-income apartment complexes, and the most important deterrent to crime, are the presence of fences and security guards or doormen. ${ }^{66}$ The insecurities of the Divis Flats complex can be more easily understood within the framework of Newman's groundbreaking work. The complex only deviates from the above-named characteristics by the fact that the Divis blocks did not contain a central, interior-facing lobby. Instead, they had exterior flights of stairs and elevators located at the ends of the walk, path and row corridors.

While Jane Jacobs' postmodern interpretations of the urban landscape exposed the fundamental need for social and community amenities, Newman's work focused more on the ways that design effects security. In fact, the two concerns both relate to architectural design, and become further intertwined when one considers that continued presence of residents throughout a complex, utilizing amenities like community centers, shops and parks, can deter crime just as much as a lighted stairwell or a doorman.

There was a shocking lack of thought put into the amenities of Divis Flats by the Laing Construction Company. I first learned about the tragedies of the complex when I visited the Divis Community Center in August of 2005; however, that building was not built until 1983, almost 15 years after the original 12 blocks were constructed. Initially, the only amenities at the Divis complex were a football pitch between Gilford and St. Comgall's and one behind Massereene, as well as a playground with two swing sets in front of Massereene - hardly adequate to accommodate more than a thousand children. "There's nothing for children. Well, they have a park but it's full of carry-out bags, broken bottles, no swings, no slides, no nothing," exclaimed one mother. ${ }^{67}$

In a rare collection of first-hand stories published by the Divis Residents' Association in 1983 called Balconies, Brits and Binlids, a girl named Veronica recalls her childhood.

I remember one of the things we used to do if we were bored was to walk round the balconies looking for black bows on the doors and go in to see the corpse. It didn't matter if you knew them or not. We just used to knock on the door and ask to see the body, and people brought you in. God love some of those poor people, we must have had them tortured, 'cos if it was a good corpse we'd go back a couple of times. ${ }^{68}$

Unfortunately, the lack of amenities for children not only led to general boredom, but also encouraged petty crime and vandalism. What few amenities were provided for children were not very safe because there were no benches on which adults could sit to supervise, and adequate views of the play areas from the 
flats were obstructed. A close examination of the floor plans of the flats, as well as the placement of corridors toward Divis Tower reveals that most kitchen and living spaces were oriented away from the play areas. Only Gilford, St. Comgall's, Farset, Masserene and Church blocks had living spaces with views of either the playground or a soccer pitch, and these structures only housed 200 of the more than 850 units. Parents living on five of the seven floors at Cullingtree, Milford and St. Peter's could supervise children in play areas only from the windows of their bedrooms, and those living directly on the path and row levels could not see over balconies to the courtyard from their flats. Parents unfortunate enough to live in Pound, Whitehall, St. Brendan's and St. Jude's blocks had no view of play spaces on the ground. Thus, many children were encouraged to play in the corridors. However, as trash chutes backed up and dogs relieved themselves in these areas they became extremely unsanitary places for children. In a 1987 survey of housing and health conditions at Divis Flats, one father explained that his child had contracted an intestinal parasite from playing near the blocked up trash chutes and dog feces on the balcony. ${ }^{69}$ Interestingly, in 1968 a Federal Housing Act was passed in the United States calling for no children to be housed in high-rise structures above the fifth floor because of the inability to supervise them.

Besides community centers and playgrounds, the other major amenity that dramatically improves living conditions by ensuring the presence of residents and providing clear definitions of public and private space is landscaping. In 1922, in his planned "Contemporary City for 3 Million People," Le Corbusier explained that planted areas are, "the only way to promote healthy conditions and create a tranquil atmosphere." " He went on to note that "the new spirit of architecture and the emerging art of urban planning can satisfy our deepest needs by bringing nature into the city landscape." 71 Surrounded by these new high-rises, he acknowledged that "we must bridge the painful gap between man and his city by introducing a means that fits into both scales... we must plant trees!"72 There were no trees at the Divis Flats complex.

Newman notes that:

We have found that physical subdivisions, if clearly defined and related to access paths, amenities, and entries, encourage occupants to adopt proprietary attitudes and to exert potent territorial prerogatives which serve as natural and significant deterrents to crime." 73

There were no physical subdivisions (including landscaping or fences) related to paths, amenities or entries at Divis Flats. Much of Newman's work in the early 1970s focused on insecurity at Pruitt-Igoe in St. Louis. There, he observed that the simple placement of a chain-link fence around the entrance to one building resulted 


\section{Divis Flats}

in an 80 percent reduction in crime and vandalism. ${ }^{74}$ His work also noted that if fewer residents have access to lobbies and corridors there is an increase in the sense of ownership and a dramatic reduction in crime and vandalism. At the Divis Flats, with its three levels of continuous corridors, army units were able to patrol freely, but feelings of spatial control for residents were entirely denied.

Additional security concerns related more to a lack of maintenance or intentional malfunction than initial architectural design, and included broken elevators, railings and lights. In the mid 1980s one man died after he fell four floors, and a child died when he fell through a broken railing on the stairs. Sluka noted that "residents have complained over the years that soldiers have broken lights on the walks in the complex to prevent their being silhouetted for snipers and to take advantage of their rifle-mounted night scopes." 75 This claim is perhaps a bit far-fetched, but it is true that there was not adequate lighting in stairwells, links or corridors, which contributed to an increase in feelings of insecurity for residents. Feelings of insecurity and mistrust of the military were also heightened when, as one resident explained, "there were two soldiers killed at the lift round at Pound block. The IRA killed them with a bomb. I think it was hidden in the lift. Then the army came and cut the cables on all the lifts and left the flats without lifts for years after that." 76

Following the creation of the Divis Demolition Committee and the media attention that followed their campaign for complete demolition, the Northern Ireland Housing Executive hired ASSIST Architects in March of 1983. The architects' role was to conduct a physical assessment of the Divis Flats, but the ulterior motive behind this survey was to avoid total demolition (which would require the building of approximately 900 new houses) in favor of cheaper mass renovation. The politics behind the demolition movement of the Divis residents was further complicated by the fact that Belfast City Council was pushing to complete the M1 highway. The highway was planned to run from the southern suburbs to just north of the city center, and would continue out past the airport and eastern suburbs, but it would be built directly through the lower Falls area (only 20 metres from Whitehall block). The highway was first proposed in the early 1960s and can now be seen as one of the catalysts for the preliminary mass slum clearance program of that same decade. However, the outspoken demands that Pound Loney residents to be re-housed within the safety of the lower Falls, as well as Protestant politicians' concerns over a potentially threatening demographic shift, meant that the M1 project had been put off for nearly 20 years. By 1983 the issue had resurfaced, and in conjunction with concerns over the inhabitability of the flats, the NIHE was forced to act.

ASSIST came to the conclusion that demolition of Whitehall and Farset blocks was unavoidable, a ruling that benefited both the highway builders and the British Army (who could not fully monitor Farset because of its perpendicular position to Divis Tower). But they also pointed to St. Brendan's and Pound as necessitating demolition, stating in their report that, "we have recommended more 
demolition than is now proposed, and more extensive modernization of the remaining flats. We believe if this work is not carried out, the flats should be classified as unfit for habitation." 77 The cost of the work to be done, including the building of 170 terrace style houses in the area was $£ 10.8$ million. They recognized that residents of Divis would not support this finding, and that they favored complete demolition of the 12 blocks, but stated that:

We are not in a position to propose such action since it would be largely a political rather than a technical decision. If all the 795 flats were demolished, there would only be room for about 280 , at the most 300 , traditional houses on the site. A further 500 houses would have to be provided in other areas. ${ }^{78}$

Although in coming to this conclusion, ASSIST failed to recognize that, according to a pole conducted by the Divis Joint Development Committee, residents would be more than willing to move outside of the area if it meant escape from the flats. ${ }^{79}$ They proposed a breaking up of the remaining eight blocks of flats, which would remove many hazardous links and increase overall security by limiting access to individual terraces (i.e. Newman's concept of defensible space). This breaking up of the continuous terraces would help to facilitate a sense of ownership and community for Divis residents.

Unfortunately, the plan was only ever partially implemented by the NIHE. Whitehall, Farset, St. Brendan's, Pound and the part of Cullingtree that connected to them, and was also closest to the M1 route, were all demolished in 1983 and 1984. However, proposed renovations for the remaining 413 flats never came, nor did the plan to break up the links. Ultimately, problems continued to plague Divis until the remaining blocks were finally demolished a decade later.

ASSIST's 1983 report breaks up the numerous physical problems of the flats, with the most emphasis placed on "damp" and mold-related issues, which have been shown to cause respiratory problems. This correlation is supported by the findings of the 1987 housing and health survey, which concluded that 36 percent of Divis children had frequent coughs, 36 percent had wheezy or whistling sounds and 10 percent had symptoms of asthma, compared to only single digits of children at a nearby terrace housing estate. ${ }^{80}$ One resident explained:

When we moved into Gilford Row, there was no dampness but they were new, but now there is a lot of damp. There was dampness in my own flat in the children's room on the ceiling, it was to do with the balconies, the water lying on the balconies then when there was heavy rain, the water used to come in 


\section{Divis Flats}

through the ceiling they were very very damp. The rooms were damp and cold for the children to sleep in. There was heating but it was more often off than on. ${ }^{81}$

Problems with mold in the flats came about because of the use of inadequately insulated concrete in a cold climate. Concrete is already one of the most inefficient building materials in a northern climate, and most residents could not afford to heat their flats sufficiently. The ASSIST study showed that the average resident would have to pay more than 9 percent of their income to adequately heat a three bedroom flat. ${ }^{82}$

Meanwhile, condensation quickly formed when the temperature of rooms fell below that of walls and windows, encouraging the growth of mold. Also, the design of corridors without proper drainage pipes meant that water easily collected and seeped down into the flats. The persistent mold problem was made worse by the impractical design of the drying tower for laundry between St. Peter's and St. Comgall's blocks. Residents could not supervise their laundry while it was drying, so they resorted to hanging it in their flats and out of windows, causing more condensation and mold.

\section{Psychological Effects of Design}

The psychological insecurities that developed at the Divis Flats in the 1970s and 1980s are not unlike those found in many similar modern public housing projects. These include problems with persistent unemployment, alcoholism, drug abuse, depression, and a breakdown of community and family structures. These problems contributed to feelings of social exclusion, and ultimately resulted in allegiance to paramilitaries, whether as a means of controlling crime or because of resentment toward the British state.

For the young people of the flats, school had little appeal if job discrimination was inevitable, and joyriding became a favorite way to eliminate boredom. Kids would regularly steel cars from along the Falls Road, and drive them to the Divis Flats where there was a high degree of anonymity and where the RUC refused to venture, setting them on fire.

Places like this create their own problems: loneliness, alcoholism, and depression. Kids who have nowhere to play will turn to vandalism or joy-riding, or rioting, for the excitement; laying their life on the line for the thrill of it all. ${ }^{83}$

Australian sociologist Alex Marsh notes that crime and anti-social behavior not 
only destabilize neighborhoods, but also contribute to victims' feelings of social exclusion when their security needs are not adequately met. As a result the Divis community turned to paramilitaries for social control. ${ }^{84}$

Many of these "hoods" turned to drugs as an outlet for their pain, and glue-sniffers found easy sanctuary in the dark stairwells between the blocks. But substance abuse was certainly not limited to the youth of Divis Flats. One mother explained:

I think the reason why a lot of people drink now is because depression has a lot to do with it, they have nowhere to go and they are in the house all day with the children. . .I think a good majority of the people have drink problems, they can't do anything about it. They are stuck in the flats all day and they are on the dole and they have hardly any money, they can't afford to go out. . .they are bored and depressed and when they get a wee drink it takes all their problems away but the next morning they are still there. ${ }^{85}$

Over 70 percent of the households that Jeffrey Sluka interviewed in Divis Flats had members who suffered from depression, bad nerves, insomnia, alcoholism, dependence on tranquilizers, or other psychological or emotional problems. He notes the potential connections between poverty, political instability (or more likely increased feelings of insecurity) and substance abuse, saying that:

Many of these problems are the result of social, economic, and housing stress, and it is difficult to say how much they are a result of political troubles. But it is certainly the case that when the violence flares up, as it did during the hunger strike, an increasing number of residents begin to complain of depression and bad nerves, drink more, and take more tranquilizers and other prescription drugs. ${ }^{86}$

Such social problems were compounded by the break down in community that came about when the complex was built. A joint publication by the Divis Residents Association and the Town and Country Planning Association of London described the social bonds of the old, tightly knit Pound Loney community. ${ }^{87}$ The residents of the old neighborhood who were re-housed at the flats in 1969 attempted to maintain their cohesion, but the physical structure of the blocks made it hard to gather together. There were no public meeting places in the complex until the community center was built in 1983. In his 1945 book Rebuilding Our Communities, 
which criticized the structure of modern cities, Walter Gropius wrote, "I am deeply convinced that the building of neighborhood community centers is of even greater urgency than housing itself." ${ }^{\prime 88}$ He elaborates that:

The centers could best be developed in connection with the schools, and would enable the people to control their own fate more efficiently. The cost of these administrative units would soon be repaid, for the usual unproductive expenditures for relief, delinquency and crime decline as rapidly as the initiative of the people grows. ${ }^{89}$

The subsequent rise of successful community groups like the Divis Residents Association and Divis Demolition Committee immediately after the Community Center's construction, demonstrate the power that social amenities have in psychologically transforming an environment. By 1987 the Divis Joint Development Committee formed, and continued to raise public awareness, and empower residents to change their environment without the help of paramilitaries. It was ultimately these groups that ensured the safety of Divis residents, by ensuring total demolition and the building of traditional terraced and row houses in their place.

Numerous physical deficiencies at the Divis Flats contributed to feelings of psychological insecurity; namely depression, alcoholism, hopelessness and social exclusion. They also explain a general loss of faith in government at a time when political participation for Catholics was already nonexistent, and this anger and resentment meant a proportional growth in support for the republican movement and its militant factions. Additionally, the feelings of social exclusion that developed in miserable living conditions led many impoverished children to crime, and ultimately meant that the IRA and INLA were needed for community policing. Because there was no clear separation between the political and social control roles of the IRA, the organization was discredited and Divis residents indirectly punished. Mistreatment by on-edge security forces created further resentment and an even stronger allegiance to republicanism.

\section{Conclusion}

Through an examination of the course of conflict in Northern Ireland since 1968 a relative pattern of allegiance to the republican movement has been exposed. While this support was dictated by multiple factors, including national and religious identity and subsequent political motivations, it was also driven out of innate fear. The residents of the Divis Flats in the Catholic Falls Road area of West Belfast were placed into an environment that was physically conducive to crime and insecurity, and actually made them more vulnerable, exactly at the time when civil conflict 


\section{Megan Roy}

erupted and security was needed the most. I make no claims that the structure of the Divis Flats caused the Troubles; however, I do offer that it contributed to conflict in very important and often overlooked ways.

A number of alienating and terrifying events, including the rioting of August 1969, the introduction of warrantless seizures, internment, the gruesome murders of a number of Falls Road Catholics by the Shankill Butchers in 1975 and 1976, and the use of plastic bullets by the British military all contributed to an increase in support for the Irish Republican Army and the Irish National Liberation Army. In fact, in 1983 over 50 percent of residents at the Divis Flats actively supported at least one of these paramilitaries. ${ }^{90}$

The need for physical security is a fundamental one, and one that must be met before thoughts on politics or nationality can be even marginally considered. Thus, for many of Belfast's urban poor, Protestant and Catholic alike, the need for stable housing and employment is primary. A shocking statistic to consider, and one which challenges fundamental interpretations of conflict in Northern Ireland, is that in 1983 over 76 percent of Divis residents expressed no interest in politics at all! ${ }^{11}$ Social historians have identified competition for jobs and housing as a contributing factor to the conflict, but until now there has been little reflection on the direct physical role that public housing has played in dictating the course of conflict.

The Laing Construction Company was contracted to build the Divis Flats in the late 1960s because of their ability to build with the SECTRA concrete system of steel frame and pre-formed slabs. This system was cost-efficient (at least in the short run) but turned out to be disastrous in Belfast's damp and cold northern climate, where heating is costly and concrete highly inefficient. Condensation quickly led to the growth of mold, which contributed to a significant increase in respiratory ailments for residents, as did the asbestos insulation meant to insulate the concrete. In a health survey conducted in 1987 more than 80 percent of children living at the Divis Flats were found to be unable to keep warm during the winter, compared to only 31 percent of children living in a neighboring terraced estate. ${ }^{92}$

Considering the numerous other physical deficiencies at the Divis Flats, including easily clogged trash chutes, broken elevators and an impractical laundry system, not to mention the continuous-terrace design that discouraged feelings of ownership, safety and community, it is no wonder that four of the blocks stood for only 15 years. The remaining eight were demolished after a mere 25 years! The poor design and malfunction of the complex resulted in greater feelings of social exclusion for a minority group already isolated from society. This frustration ultimately led to an allegiance for the IRA and INLA.

So, what on earth went through the minds of bureaucrats and politicians at the Department of the Environment and the Housing Executive? There were multiple motivations for building the Divis Flats in 1968, including political, economic and military considerations. Certainly, many city planners had faith in the 


\section{Divis Flats}

popular rhetoric of Le Corbusier's modern housing theories, believing that life for this poor community would be greatly improved through slum clearance programs. In fact, the Divis complex offered many internal amenities, such as running water and central heating, which had been absent from $19^{\text {th }}$ century two-up two-downs with a communal loo out the back. But while these "modern" amenities made for a good advertising campaign, equally significant exterior amenities were not provided. The lack of landscaping and spatial definition meant that the open spaces between blocks became a no man's land of "hoods," drug addicts and joyriders... and a good place to start a bonfire if the opportunity presented itself. Furthermore, the initial absence of a Community Center, as well as the impersonal structure of high-rises itself, resulted in a breakdown of the community bonds that had once kept the Pound Loney-ites safe. ${ }^{93}$ Obviously, these essential parts of a community were left from the drawing board because of economic constraints. Le Corbusier's utopian vision for a "Radiant City" was not one where there were budgetary cuts... or poor people at all for that matter.

An additional reality was that Belfast city planners wanted to make way for a four-lane highway, running precisely through the Lower Falls district. As was the case throughout the United States and Western Europe after World War II, the growth of middle class suburbs and "white flight," or Protestant flight, as was the case in Northern Ireland, meant that workers needed an easy way to get to their jobs in the city. In Atlanta, Georgia, the construction of a major interstate came about at the expense of the old Sweet Auburn neighborhood, ripping apart the heart of the city's African-American community.

The building of interstates through disadvantaged communities is not just an economic decision, however. There are also political careers to be considered, and in Northern Ireland politics is always of issue. By concentrating West Belfast's Catholic community in high-density structures under the guise of modern living and community safety, unionist politicians could maintain a large Protestant constituency in the neighboring Shankill Road and Sandy Row. However, this political tactic also came at the expense of social harmony. By encouraging the separation of West Belfast's Protestant and Catholic communities bureaucrats were helping to foster feelings of "the other," which made conflict more pronounced. Granted, certain real barriers like the Peace Line were, at times, needed for protective reasons. But in the long run the division of Belfast into a patchwork of Green and Orange, Tricolour and Unionjack, only intensified social divisions and heightened conflict. By separating Belfast's working-class Protestant and Catholic communities, bourgeois bureaucrats ensured that they would continue to perceive each other as the enemy, rather than recognize common positions of economic disadvantage.

Civil unrest was supposed to be controlled by the British Army, which began patrolling the Falls district shortly after the riots of 1969. They were initially greeted with goodwill by the residents of Divis Flats and were seen as less biased than the local RUC because they were outsiders. However, many of the events that 
contributed to an increase in allegiance to the IRA, such as internment in 1971, also resulted in a breakdown of relations between Catholic residents and army patrols. Such feelings of "us versus them" were only encouraged by an architectural design that positioned the army up in a 20-floor tower, and the front door to every resident's flat down below in a position of optimal surveillance. Furthermore, the design of a system of continuous terraces throughout the complex, connected by links of stairs and elevators, made for easy military patrolling, but simultaneously denied residents any feeling of ownership or control over their environment. This loss of control was especially important when it came to the monitoring of children.

Because of the positioning of the flats, with living spaces out the back side and bedrooms under and above the terraces, few families were able to adequately monitor their children down on the ground. There were only two soccer pitches in the entire 850-family complex and one playground. But because of a lack of benches for parental supervision and sufficient line of sight from flats on upper floors, bored children were easily lured into antisocial behavior.

The epidemic of glue-sniffers, vandals and joyriders that overtook the Divis complex in the 1970s and 1980s, terrorizing residents already dealing with external threats to their security, meant a significant need for social control. Enter the IRA. The role that Republican paramilitaries have played in community policing has always been overlooked by a media that prefers to depict them as violent terrorists. I do not deny that the Provisional IRA, and especially the more radical INLA, have been involved in hundreds of tragic bombings and murders over the last 35 years. Regardless of whether one believes that their goal of a united Ireland is a legitimate one, the brutality of many of their militant actions, resulting in the loss of innocent life cannot, I believe, be justified. Republican leaders like Sinn Fein's Gerry Adams have shown that political participation is a much more efficient way of achieving a resolution to the Troubles. However, the IRA's social control position in the Catholic ghettos of Belfast was made necessary by the absence of an adequate police force and mistrust in government. In 1983 over 76 percent of residents at the Divis Flats believed that the IRA and INLA were needed to control antisocial behavior. $^{94}$ A statement released by the Provisional IRA in September of 1976 read:

The $2^{\text {nd }}$ Battalion, Belfast Brigade IRA, warn all thieves in the area to cease their activities forthwith, or else suffer the consequences. The people already suffer severe British oppression and the Republican Army needs all its resources to resist their terror. The activities of these local criminals adds to the suffering of the people, and aids the Brits by channeling Republican activity into a policing role. The $2^{\text {nd }}$ Batt. warn in particular a crime-ring operating from the 


\section{Divis Flats}

Divis Flats complex and in and around the lower Falls. ${ }^{95}$

In January of 1982 a number of elderly women were attacked and robbed in and around the Divis Flats, and a young woman was brutally raped in a stairwell. On February 2, a 17-year-old was apprehended by the IRA for these crimes, after a number of witnesses came forward. He was shot in both legs just above the knees, and three fellow "hoods" involved were forced to read statements at local clubs apologizing to the girl, her family, and the community at large. ${ }^{96}$

While the physical structure of the Divis Flats encouraged rampant criminal behavior within the complex, it also perpetuated physical and psychological divisions between the Catholic and Protestant communities. In addition to such social divisions, the complex also contributed to feelings of resentment toward the British army by Catholic residents. Residents lost faith in a government that seemed to have abandoned them, and turned to militancy when political participation was not an option. Within Catholic society, the physically impersonal and alienating structure of the flats caused a rapid deterioration of traditional community bonds, allowing problems with crime and drug abuse to flourish among young people. Such crime only necessitated the presence of paramilitaries for social control, the very presence of which allowed residents to be further victimized by the British army and loyalist paramilitaries.

Architectural design alone cannot be blamed for the problems that emerged at Divis Flats, because economic constraints on the Housing Executive (the result of Thatcherite cuts in social spending in the 1980s), as well as unavoidable, longstanding political allegiances and cultural differences certainly contributed to unstable social conditions as well. However, in not recognizing the role that public housing design and other social welfare programs play in stabilizing a community, one fails to recognize the issues that effected citizens' everyday lives.

An examination of the Divis Flats demonstrates the fundamental ways that architectural design can contribute to the ills of a community by denying basic needs for security and encouraging social exclusion. It was these factors that ultimately drove residents to seek protection from the IRA and INLA and which perpetuated conflict.

Feelings of insecurity about one's residential environment often lead to the adoption of a negative and defeatist view of oneself, to ambivalence about job finding, and to expressions of general impotence in the capacity to cope with the outside world. The secure residential environment - understood by a resident as a haven and interpreted by outsiders as the expression of the inhabitants' ego - may be one 


\title{
Megan Roy
}

\author{
of the most meaningful forms of social rehabilitation \\ available to the family and to society. ${ }^{97}$
}

- Oscar Newman

I am grateful for the generous support of Professor Jeffrey Cox, who served as my primary thesis adviser, encouraging me throughout my research endeavors and allowing me to incorporate my dual interests in the history of conflict in Northern Ireland and the legacy of Modernist public housing. Additionally, I am indebted to Professor Barbara Mooney in the School of Art and Art History. She not only edited my entire thesis and served on my committee, she opened my eyes to the discipline of architectural history and theory. I would also like to thank Bob Kirby, Associate Director of the Honors Program, for his support. Lastly, I would like to thank Professor Shelton Stromquist for serving on my thesis committee and for inspiring me to get involved in the issues of affordable housing.

\section{Endnotes}

1 Le Corbusier, La Ville Radieuse (New York: The Orion Press, 1967) 37. Speech from a 1930 meeting of CIAM.

2 Jane Jacobs, The Death and Life of Great American Cities (New York: Random House, 1961), 31.

3 Jeffrey Sluka, Hearts and Minds, Water and Fish: Support for the IRA and INLA in a Northern Irish Ghetto (London: JAI Press Inc., 1989), 45.

4 Katharine Bristol, “The Pruitt-Igoe Myth," Journal of Architectural Education 44 (1991): 16371.

5 Sudhir Venkatesh, American Project (Cambridge: Harvard University Press, 2000), 9.

6 Sluka, Hearts and Minds, 45

7 Jack Holland, Hope Against History (New York: Henry Holt and Company, 1999), 117.

8 Personal conversation at the Divis Community Center, August 15, 2005.

9 Diane Ghirardo, "The Architecture of Deceit," Theorizing a New Agenda for Architecture, ed. Kate Nesbit (New York: Princeton Architectural Press, 1996), 390.

10 See Coogan Holland, Tim Pat, The IRA (New York: Palgrave, 2002) and John McGarry and Brendan O'Leary, Explaining Northern Ireland (Oxford: Blackwell Publishers, 1995).

11 Maryanne Elliot, The Catholics of Ulster (New York: Basic Books, 2001), 86.

12 Research Unit Northern Ireland Housing Executive, Public Attitudes Survey: 1996/1997

Report (Belfast: The Seventh Biennial Survey of Public Attitudes, 1998).

13 Divis Demolition Committee, The Dreadful Enclosure (Belfast: Art and Research

Exchange, 1983), 10.

14 Gerry Dawson, Planning in the Shadow of Urban Civil Conflict: a Case Study from Belfast

(The University of Liverpool Department of Civic Design, Working Paper, 1984), 18.

15 Frederick Boal, Shaping a City: Belfast in the late twentieth century (Institute of Irish Studies: Queen's University Belfast, 1995), 14.

16 Ibid.

17 Holland, Hope Against History, 48.

18 Ibid., 61.

19 Sulka, Hearts and Minds, 172.

20 Holland, Hope Against History, 68

21 Sluka, Hearts and Minds, 56.

22 Ibid.

23 Irish Republican News, "IRA Spokesman Statement," April 1, 1982. 


\section{Divis Flats}

24 Venkatesh, American Project, 156.

25 Irish Times, "Mason Blames Unemployment," September 28, 1976.

26 Sluka, Hearts and Minds, 196.

27 Holland, Hope Against History, 93.

28 Today an enormous mural of Bobby Sands is painted on the side of the Sinn Fein center on the Falls road, and is retouched every year by artist Danny Devenny.

29 Sluka, Hearts and Minds, 271-72.

30 Ibid., 71.

31 Paul Bew and Gordon Gillespie, Northern Ireland: A Chronology of the Troubles 1968-1999 (Maryland: Scarecrow Press, 1999), 189.

32 Holland, Hope Against History, 136.

33 Bew, Northern Ireland, 223.

34 Sluka, Hearts and Minds, 287.

35 Irish Times, "Adams and Hume Speak of Self-determination," August 28, 1994.

36 Belfast Telegraph, "Statement by the INLA," August 22, 1998.

37 Abraham Maslow, Motivation and Personality (New York: Harper, 1954).

38 Northern Ireland Housing Executive, Public Attitudes Survey, 26.

39 Jacobs, The Death and Life of Great American Cities, 36.

40 Ibid., 30.

41 Robert A. Liston, Terrorism (New York: Thomas Nelson, 1977), 23.

42 Divis Community Arts Project, No Place for a Dog (Belfast: Divis Community Arts Project, 1990), 8. From the collection of the Linen Hall Library, Belfast.

43 Tim Blackman, Eileen Evason, Martin Melaugh and Roberta Woods, Housing and Health

in West Belfast: A Case Study of Divis Flats and the Twinbrook Estate (Belfast: Divis Joint Development Committee, 1987), 11.

44 Department of the Environment, Transport and Regions, "Quality and Choice: A Decent Home for All," The Housing Green Paper (London, DETR, 2000), paragraph 12.22.

45 Blackman, Housing and Health in West Belfast, 11.

46 Oscar Newman, U.S. Department of Housing and Urban Development, Creating Defensible Space, 1997, 3.

47 Oscar Newman, Creating Defensible Space (New York: Macmillan, 1972).

48 Ibid., 51.

49 Divis Demolition Committee, The Dreadful Enclosure, 3.

50 Sluka, Hearts and Minds, 206.

51 Dawson, Planning in the Shadow of Urban Civil Conflict, 12. The Department of the Environment directly oversees the Housing Executive.

52 NIHE memo, 6-12-79, from Dawson, 18.

53 R. Cowan, "Belfast's Hidden Planners," Town and Country Planning, 1982, 163-65.

54 P. Somerville, "Explanations of Social Exclusion: Where Does Housing Fit It?," Housing

Studies 13, no. 4, 772.

55 Alex Marsh, "Housing and the Social Exclusion Agenda in England," Australian Journal of Social Issues 39, no. 1 (Feb. 2004), 7.

56 Sluka, Hearts and Minds, 185.

57 Ibid., 172.

58 F. Burton, The Politics of Legitimacy: Struggles in a Belfast Community (London: Routledge, 1978), 88.

59 Venkatesh, American Project, 199.

60 Ibid.

61 Newman, Creating Defensible Space, 12.

62 Kathleen McGill, "A Burning Experience," Muses from the Mill (Belfast: Conway Education Centre, 2003), 35. 


\section{Megan Roy}

63 Holland, Hope Against History, 59.

64 Ibid., 5. On May 3, 2007, Gusty Spence announced the dissolution of the UVF. The full decommissioning of weapons is still at issue.

65 Sluka, Hearts and Minds, 56.

66 Newman, Creating Defensible Space, 22.

67 Divis Study Group, Balconies, Brits and Bin Lids: An Oral History of Divis Flats, Belfast

(Belfast: Divis Study Group, 1998) Lily, 57.

68 Ibid., Veronica, 42.

69 Blackman, Housing and Health in West Belfast, 10.

70 Le Corbusier, Urbanisme, or The City of Tomorrow and Its Planning (London: J. Rodker, 1929), 92.

71 Ibid., 71.

72 Ibid., 70.

73 Newman, Creating Defensible Space, 53.

74 Ibid.

75 Sulka, Hearts and Minds, 175.

76 Balconies, Brits and Bin Lids, Thomas, 54.

77 J. Gilbert and J. A. Horan, The Divis Flats (Belfast: ASSIST Architects), report published July $5,1983,1$.

78 Gilbert, The Divis Flats, section 17.5.

79 Divis Demolition Committee, The Dreadful Enclosure.

80 See Blackman, Housing and Health in West Belfast.

81 Balconies, Brits and Bin Lids, Maura, 51.

82 Gilbert, The Divis Flats, section 15.4.

83 Divis Community Arts Project, No Place for a Dog, 8.

84 Marsh, "Housing and the Social Exclusion Agenda in England," 18.

85 Balconies, Brits and Bin Lids, Maura, 49.

86 Sluka, Hearts and Minds, 280.

87 Divis Demolition Committee, The Dreadful Enclosure, 2.

88 Walter Gropius, Rebuilding our Communities (Chicago: Paul Theobald, 1945), 54.

89 Ibid., 55.

90 Sluka, Hearts and Minds, 115.

91 Ibid., 113.

92 Blackman, Housing and Health in West Belfast, 13.

93 See Hilde Heynen, "Modernity and Domesticity: Tensions and Contradictions," Negotiating

Domesticity: Spacial Productions of Gender in Modern Architecture, ed. Gulsum Baydar and

Hilde Heynen (Routlege, 2005).

94 Sluka, Hearts and Minds, 123.

95 Republican News, "Criminal Activity in Divis Flats," September 25, 1976.

96 Sluka, Hearts and Minds, 129.

97 Newman, Creating Defensible Space, 187.

Megan Deirdre Roy graduated with honors in history in 2006. In 2005, she was awarded the History Department's Burke Fellowship, allowing her to conduct research in Belfast, Northern Ireland for her thesis. The following year she was awarded the Kay Keeshan Hamod Scholarship from the College of Liberal Arts and Sciences, as well as a Collegiate Fellowship from the Honors Program. During her senior year, she served as an undergraduate research assistant for Professor Barbara Mooney in the School of Art and Art History. Most recently she was awarded the 2006 Stow Persons Prize for the best undergraduate honors thesis in history. This fall she begins a master's in architecture at Washington University's School of Architecture in St. Louis. 